Papers

\title{
Hydrological response of hydrographic sub- basins in the Piracicaba River Basin - Southeast Region of Brazil
}

\author{
Ana Claudia Pereira Carvalho ${ }^{1}$ \\ Reinaldo Lorandi ${ }^{2}$ \\ José Augusto Di Lollo ${ }^{3}$ \\ Eduardo Goulart Collares ${ }^{4}$ D \\ Luiz Eduardo Moschini ${ }^{5}$ iD
}

$\begin{array}{ll}\text { Keywords: } & \text { Abstract } \\ \text { Watershed } & \text { The use of water for several human needs, associated with climate change, indicates how } \\ \text { Flow } & \text { important it is to understand the response of watersheds, in order to provide adequate } \\ \text { Water resource } & \text { planning and management of water resources. This study was carried out in two pairs } \\ \text { management } & \text { of hydrographic watersheds, in the Piracicaba River Basin, southeast of Brazil, analyzing } \\ \text { Rainfall } & \text { water response, integrating in-situ collected precipitation and flow data, natural } \\ \text { Runoff } & \text { environmental attributes, and anthropic environmental data. To support the analysis, } \\ & \text { Surface Runoff Potential Charts (SRPC) were made. The evaluation of the physical } \\ & \text { characteristics of the sub- watersheds (SW(A) and SW(B)) shows that these areas present } \\ & \text { very low to low potential, indicating greater infiltration capacity. The use and coverage } \\ & \text { of the soil partially justifyies flow changes in pair 1, since SW(A) has a larger extent of } \\ & \text { agricultural areas that can use irrigation. SW(B), even with a greater variety of crops, } \\ & \text { has a smaller cultivated area and tends to demand less water. As for pair 2, the low } \\ & \text { runoff potential was mainly due to the predominance of flat relief in the sub-basins. Their } \\ & \text { soils present a higher fraction of silt and clay, with thicknesses }>5 \mathrm{~m} \text { in SW(C) and } \\ & \text { varying from 0.5m, reaching depths above 5m in SW(D). The physical properties of these } \\ & \text { soils do not provide a low flow rate, but when associated with the low slope of the land, } \\ & \text { geological characteristics and low drainage density are configured in regions where the } \\ & \text { flow flows more slowly, contributing to the evaporation and infiltration process. The use } \\ & \text { and coverage of the soil also partially justifyies the flow oscillations, due to anthropic } \\ & \text { activities in SW(C) and SW(D), such as irrigation and spraying of citrus, fertirrigation of } \\ & \text { sugarcane, irrigation of seedling nurseries, directly interfering with the availability of } \\ & \text { surface water. }\end{array}$

${ }^{2}$ Universidade Federal de São Carlos - UFSCar, São Carlos, SP, Brazil. lorandir@gmail.com

${ }^{3}$ Universidade Estadual Paulista Júlio de Mesquita Filho - UNESP, Ilha solteira, SP, Brazil. jose.lollo@unesp.br

${ }^{4}$ Universidade do Estado de Minas Gerais - UEMG, Passos, MG, Brazil. eduardo.collares@uemg.br

${ }^{5}$ Universidade Federal de São Carlos - UFSCar, São Carlos, SP, Brazil. lemoschini@ufscar.br 


\section{INTRODUCTION}

Water is a fundamental natural resource for socio-economic development. The growing demand for water resources, combined with their limited availability and inadequate management, has made it difficult to balance supply and preservation in various regions of the world (TIKHAMARINE et al., 2020), as environmental, economic and social conditions directly affect the relationship between climate change and the availability of water resources (MEHBOOB; KIM, 2021).

The global projection scenarios show that in the future, approximately $30 \%$ of today's water expenditure will be supplied by unsustainable water resources, underscoring that by 2099 this number will have increased by approximately 40\% (WADA; BIERKENS, 2014).

This situation is not different in Brazil, which is complicated by a sense of abundant water resources. This concept of abundance covers problems of contamination, pollution, availability and demand (FERREIRA et al., 2020).

The current concern includes ensuring water in a suitable quantity and quality for both the contemporary and future population, maintaining environmental balance. It is therefore essential to manage and plan watersheds in order to guarantee the preservation of the hydrological, biological and chemical functions of ecosystems (LELIS et al., 2020).

Water resource management in river basins relies primarily on temporal data from hydrological monitoring, directly related to river flows (BESKOW et al. 2016). Continuous flow measurements should be carried out in rivers, as this makes it possible to verify temporal variation. However, in developing countries that cover continental proportions such as Brazil, monitoring is generally not enough (MELATI; MARCUZZO, 2016). The lack of historical series of streamflows is one of the problems for the adequate management of water resources (BESKOW et al., 2016).

It is noteworthy that both hydrology on a regional scale and the characterization of flow regimes enable the understanding of the hydrological matrix's function, which institutes the eco-hydrological functioning of nature (YU et al., 2020). For this purpose, public policies (ANA, 2011) have used hydrological regionalization, based on homogeneous areas. These hydrological data are either used to quantitatively estimate a variable of interest in a watershed that has not yet been evaluated or to improve the estimates in watersheds with short historical series of streamflows (RAO; SRINIVAS, 2006; MELATI; MARCUZZO, 2016). Undoubtedly, in areas with notoriously different hydrological characteristics, the same hydrological regime cannot be considered (RAO; SRINIVAS, 2006).

The regionalization method uses reference flows to manage water resources in order to guarantee water supply during periods of drought (LELIS et al., 2020). In addition to the analysis of fluviometric data, it is also essential to assess rainfall, an effective environmental attribute that can directly influence a watershed's water regime. The relationship between meteorological and hydrological data is challenging when performing data modelling, given the high spatio-temporal variation between these sets of data. However, understanding these associations can help guarantee future freshwater security in the face of climate change (SUMAN; MAITY, 2019). Understanding the hydrology behind the river flow, mainly regarding how the flow changes and the causes for that change, enables the assessment of possible risks to water safety (DENG et al., 2020).

It is also essential to incorporate human activities into the analyses to comprehend the water regime of hydrographic regions, since changes in land use and cover, associated with climate change, represent risks to water supply and ecological integrity (TUNDISI; TUNDISI, 2015). For instance, a study carried out in the Luan River Basin by Wang et al. (2016) showed that anthropic actions have a greater effect on flow changes than the climate itself. Climatic variation contributed with $40.89 \%$ while anthropic activities with $59.11 \%$ of changes to the annual flow regime. In this context, the present study aimed to evaluate the water regime in two pairs of fourth-order branching sub-watersheds considering criteria established by Strahler (1957), located in the Piracicaba River Basin, in the southeast of Brazil.

It is worth mentioning that the Piracicaba River Basin not only supplies its local population, but also contributes in $46 \%$ to the supply of the metropolitan area of the city of São Paulo, by pumping water to the Cantareira System. This puts this basin's area in a critical state, given its low levels of per capita water availability, of less than $1500 \mathrm{~m}^{3} /$ hab.year (AGÊENCIA DAS BACIAS PCJ, 2021). In order to be transferred to the city of São Paulo, the headwaters of the Piracicaba River Hydrographic Basin are dammed in a set of five reservoirs: Jaguari, Jacareí, Cachoeira, Atibainha and Paiva Castro, these form the so- 
called Cantareira System (LOPES et al., 2020).

The sub-watershed pairs were selected because they represent different associations of natural conditions and human activities. In addition, an analysis of the hydrological regime in pairs of sub-basins was conducted to obtain answers in morphometrically similar areas and to evaluate which environmental factors contribute to possible flow rate differences (CARVALHO et al., 2020).

In conclusion, the analysis carried out in the present study integrated (1) the relationship among the in situ measured flow, (2) the rainfall over a 12-month period (May 2019 to April 2020) and (3) the attributes of the natural and anthropic environment of these two pairs of subwatersheds, in order to evaluate the relationship between environmental dynamics and the question of water availability, associating the surface runoff potential in these areas. The results will make it possible to present the diagnosis current situation, so that managers and decision-makers can act in strategic points of the Piracicaba River Basin (PRB), guaranteeing a sustainable use of water resources.

\section{MATERIALS AND METHODS}

\section{Study Area}

The study was carried out in fourth-order branch sub-watersheds considered morphometrically similar, in terms of drainage density, hydrographic density and circularity index (CARVALHO et al., 2020), located in the western portion of the Piracicaba River Basin (PRB), designated SW(A) from Rio da Prata, SW(B) from Ribeirão das Tabaranas, SW(C) from Ribeirão da Cachoeira, and SW(D) from Córrego dos Coqueiros, with areas, respectively, of $98.71 \mathrm{~km}^{2}, 98.42 \mathrm{~km}^{2}, 116.27 \mathrm{~km}^{2}, 115.56 \mathrm{~km}^{2}$.

PRB is part of the Water Resources Management Unit UGRHI-5 comprising one of the 22 water resources management units in the state of São Paulo. The territorial extension of
PRB is $12,655.01 \mathrm{~km}^{2}$, with $7.4 \%$ of its total area inserted in the state of Minas Gerais.

SW(A) stands out with $30.14 \%$ of its area occupied by forests, followed by $29.03 \%$ of sugarcane plantations. The land use and coverage classes that appear in evidence in SW(B), are forests, pastures, sugar cane plantations and forestry systems, occupying areas of $25.87 \%, 17.56 \%, 12.96 \%, 12.38 \%$, respectively. Characterized as an agricultural sub-basin, SW(C), occupies $49.88 \%$ of its area with sugarcane plantation. Of its total area, $22.52 \%$ is of exposed soil class that indicates the fallow of the soil in the middle of sugarcane. $\mathrm{SW}(\mathrm{D})$ is the most diverse sub-basin in terms of land use and land cover. In particular, sugarcane plantations occupy an area of $24.16 \mathrm{~km}^{2}$, followed by fields, forests, and urban areas, which correspond to $15.67 \%, 15.54 \%$, and $14.00 \%$ respectively (Figure 1 ).

The elevation in the PRB area ranges from 444 to 2037 meters. The highest region is located in Serra da Mantiqueira, in the Minas Gerais portion, and there is an altitude decrease in the central portion of PRB towards the area where the Piracicaba River meets the Tietê River, in the geological domain of the Paraná Sedimentary Basin.

The drainage density in the eastern portion is greater in relation to the central-western end of PRB, reflecting the physical characteristics of these locations. This happens as a predominance of crystalline rocks is found in the eastern end, which hampers the infiltration process, thus allowing for greater surface runoff, besides being the portion of the basin with the highest slopes in the terrain. In the central-west region, however, there is sedimentary terrain, with lower slopes, which condition the recharge of aquifers, since the lithologies and soils facilitate water infiltration.

In terms of surface water availability, PRB has an average flow of $172 \mathrm{~m}^{3} / \mathrm{s}$ and a minimum flow Q7,10 of $43 \mathrm{~m}^{3} / \mathrm{s}$ (SSRH, 2018). The reference year 2018 Water Resources Situation Report indicates the criticality ratio when the water availability per capita is below $1,500 \mathrm{~m}^{3} /$ hab.year (COMITÊ DAS BACIAS PCJ, 2019). 
Figure 1 - Location of the study area.

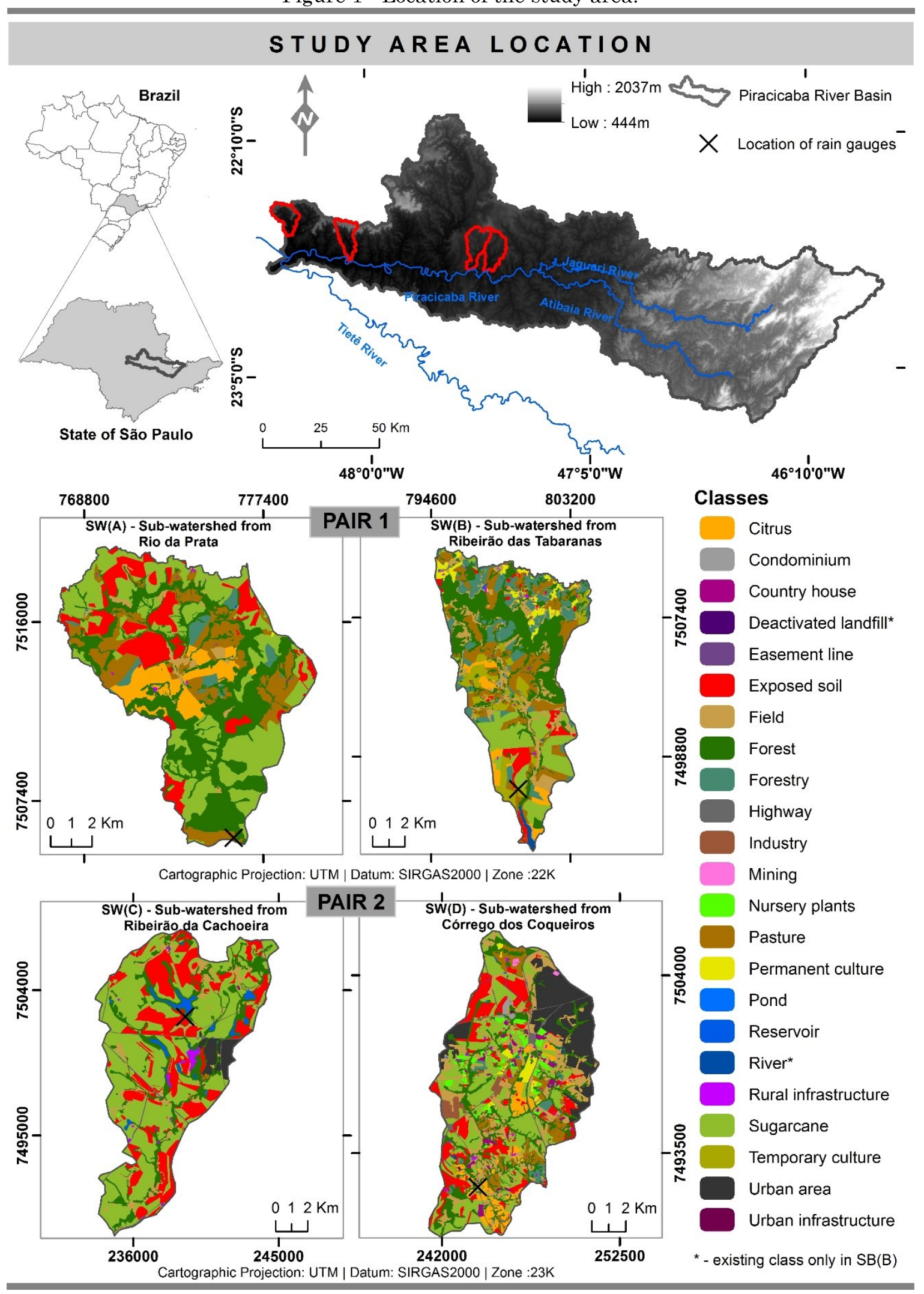

Source: Adapted from Lorandi et al (2019).

Regarding rain accumulation in 2018, the head of the Atibaia River sub-basin was the region with the highest precipitation volume, with total precipitation ranging from 1,500 to $1,600 \mathrm{~mm}$. The municipalities of Americana,
Hortolândia, Nova Odessa and Sumaré had the lowest precipitation volumes in the region, not exceeding 1,000mm (COMITÊ DAS BACIAS PCJ, 2019). 
The region of the Piracicaba, Capivari and Jundiaí River Basins (PCJ Basins) is influenced by a mass of tropical and polar Atlantic areas, with strong topography interference, such as the São Pedro mountain range (XAVIER, 2006).

\section{METHODS}

The methodological procedures applied in the two pairs of sub-watersheds inserted in PRB included data collection and preparation such as: fluviometric and pluviometric monitoring; survey and mapping attributes of natural and anthropic environments; making charts of surface runoff potential, through the method of Pejon (1992), based on the application of weights for each class of information planes, subsequently associated with the map algebra that results in the sum of information planes executed in the Raster Calculator tool of ArcGIS $10.5^{\circledR}$ software (Figure 2).

The data analysis compared in an integrative way the in situ measured flow and the rainfall, associated with factors of the natural and anthropic environment. The methodological procedures are described in the next items.

Figure 2 - Methodological procedures developed.

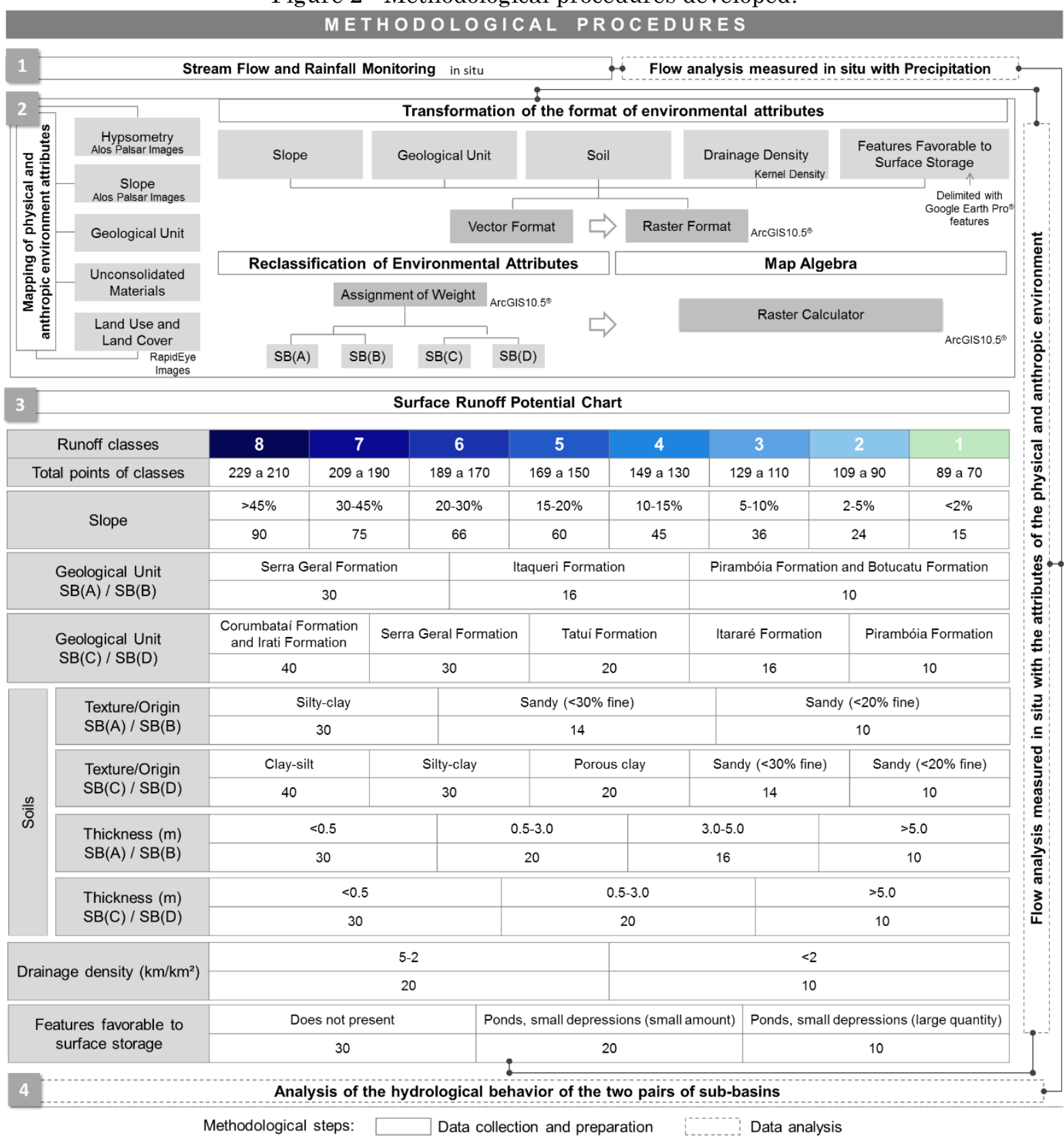

* In $\mathrm{SB}(\mathrm{C})$, the thickness and texture adopted where the urban area of Iracemápolis (SP) is located and hydromorphic materials received the weight of 30 and 40 , respectively.

Source: The authors (2021). 


\section{Fluviometric and Pluviometric Monitoring}

The initial stage of fluviometric monitoring involved bathymetry and flow velocity measurements in the cross-section of the main river, close to the exutory of each of the four subwatersheds, in a 12-month period, starting in May 2019 and ending in April 2020. Twelve flow measurements were performed in this 12 -month period, one measurement every 30 days.

The flow velocity was measured using the FP111 Global Water Flow Probe (CARVALHO et al., 2020). The methods used to measure the flow velocity followed the 1967 Hydrological Norms and Recommendations, and the 1977 Hydrometric Manual for Hydrometry Services, by the Department of Water and Electricity (SANTOS et al., 2001) (Table 1).

Table 1 - River width (m) and distance between vertical sections (m) and distribution of points for flow velocity measurement considering the respective depths and number of points.

\begin{tabular}{|c|c|c|c|c|c|}
\hline $\begin{array}{l}\text { Width of the } \\
\text { river }(\mathrm{m})\end{array}$ & $\begin{array}{c}\text { Distance between } \\
\text { vertical sections } \\
(\mathrm{m})\end{array}$ & $\begin{array}{l}\text { Width of } \\
\text { the river } \\
\text { (m) }\end{array}$ & $\begin{array}{c}\text { Distance between } \\
\text { vertical sections } \\
(\mathrm{m})\end{array}$ & $\begin{array}{l}\text { Width of } \\
\text { the river } \\
\text { (m) }\end{array}$ & $\begin{array}{c}\text { Distance between } \\
\text { vertical sections } \\
(\mathrm{m})\end{array}$ \\
\hline$<3$ & 0.30 & 15 a 30 & 2.00 & 80 a 150 & 6.00 \\
\hline 3 a 6 & 0.50 & 30 a 50 & 3.00 & 150 a 250 & 8.00 \\
\hline 6 a 15 & 1.00 & 50 a 80 & 4.00 & $>250$ & 12.00 \\
\hline \multicolumn{2}{|c|}{ Depth (m) } & \multicolumn{2}{|c|}{ Number of Points } & \multicolumn{2}{|c|}{ Point Depth (m) } \\
\hline \multicolumn{2}{|c|}{0.15 a 0.60} & \multicolumn{2}{|r|}{1} & \multicolumn{2}{|r|}{0.6} \\
\hline \multicolumn{2}{|c|}{$0.60 \mathrm{a} 1.20$} & \multicolumn{2}{|r|}{2} & \multicolumn{2}{|c|}{0.2 e 0.8} \\
\hline \multicolumn{2}{|c|}{$1.20 \mathrm{a} 2.00$} & \multicolumn{2}{|r|}{3} & \multicolumn{2}{|c|}{$0.2 ; 0.6 ;$ e 0.8} \\
\hline \multicolumn{2}{|c|}{$2.00 \mathrm{a} 4.00$} & \multicolumn{2}{|r|}{4} & \multicolumn{2}{|c|}{$0.2 ; 0.4 ; 0.6$ e 0.8} \\
\hline \multicolumn{2}{|c|}{$>4.00$} & \multicolumn{2}{|r|}{6} & \multicolumn{2}{|c|}{$\begin{array}{c}\text { Surface; } 0.2 ; 0.4 ; 0.6 ; 0.8 \text { Depth; } \\
\text { Riverbed Bottom }\end{array}$} \\
\hline
\end{tabular}

Source: Adapted of Santos et al. (2001).

The bathymetry and flow velocity measurements performed in the river crosssection in each sub-watershed allowed to delimit each cross-section using the AutoCAD ${ }^{\circledR}$ software and obtained the area of interest. Subsequently, the flow rate of each pair of sub-watersheds was calculated by the flow velocity product and area.

Moreover, in these two pairs of subwatersheds, rainfall was measured during the same fluviometric monitoring period. For this, a TFA rain gauge (model 4760) was installed in each of the sub-watersheds, which made it possible to obtain the amount of monthly precipitation. Figure 1 shows the location of the pluviometers. Subsequently, a preliminary analysis of the hydrological regime was carried out, which compared rainfall and flow data for each month in the two pairs of sub-watersheds.

\section{Survey and mapping attributes of natural} and anthropic environments

To assess the hydrological regime of the subwatersheds, the attributes of the natural environment (hypsometry, slope, geology and soils) and the anthropic environment (land use and land cover) were integrated into the analysis, all in the 1:50.000 scale (Table 2).

Figures 3 and 4 show the information plans used to understand the hydrological regime of the study areas. It is noteworthy that in these figures the items from $\mathrm{C}$ to $\mathrm{L}$ are the environmental attributes used for preparing the charts of surface runoff potential.

Table 2 - Environmental attributes used with their respective sources and mapping scale.

\begin{tabular}{l|l|c}
\hline \multicolumn{1}{c|}{$\begin{array}{c}\text { Environmental } \\
\text { Attribute }\end{array}$} & \multicolumn{1}{c|}{ Source } & Mapping Scale \\
\hline Drainage & $\begin{array}{l}\text { ANA (2013) - Agência Nacional de Águas e Saneamento Básico - } \\
\text { Federal agency responsible for the implementation of Brazilian water } \\
\text { resources management }\end{array}$ & \\
\hline Drainage Density & Authors & \multirow{2}{*}{$1: 50.000$} \\
\cline { 1 - 2 } $\begin{array}{l}\text { Features favorable to } \\
\text { surface storage }\end{array}$ & Authors/Google Earth Pro & \\
\hline Hypsometry & ASF Data SearchVertex ${ }^{\circledR}$ platform/ Alos Palsar Image & \\
\cline { 1 - 2 } Land use and land cover & $\begin{array}{l}\text { Lorandi et al. (2019) / RapidEye images dated June 2019, Planet } \\
\text { plataform }\end{array}$ & \\
\hline Lithology & Cardoso (1993); Dantas-Ferreira (2008); Pejon (1992); Valadares (2017) & \\
\hline Slope & ASF Data SearchVertex ${ }^{\circledR}$ platform/ Alos Palsar Image & \\
\hline Soils & Cardoso (1993); Dantas-Ferreira (2008); Pejon (1992) & \\
\hline
\end{tabular}

Source: The authors (2021). 
Figure 3 - Environmental attributes and their respective quantifications of sub-watersheds A and B inserted in PRB.

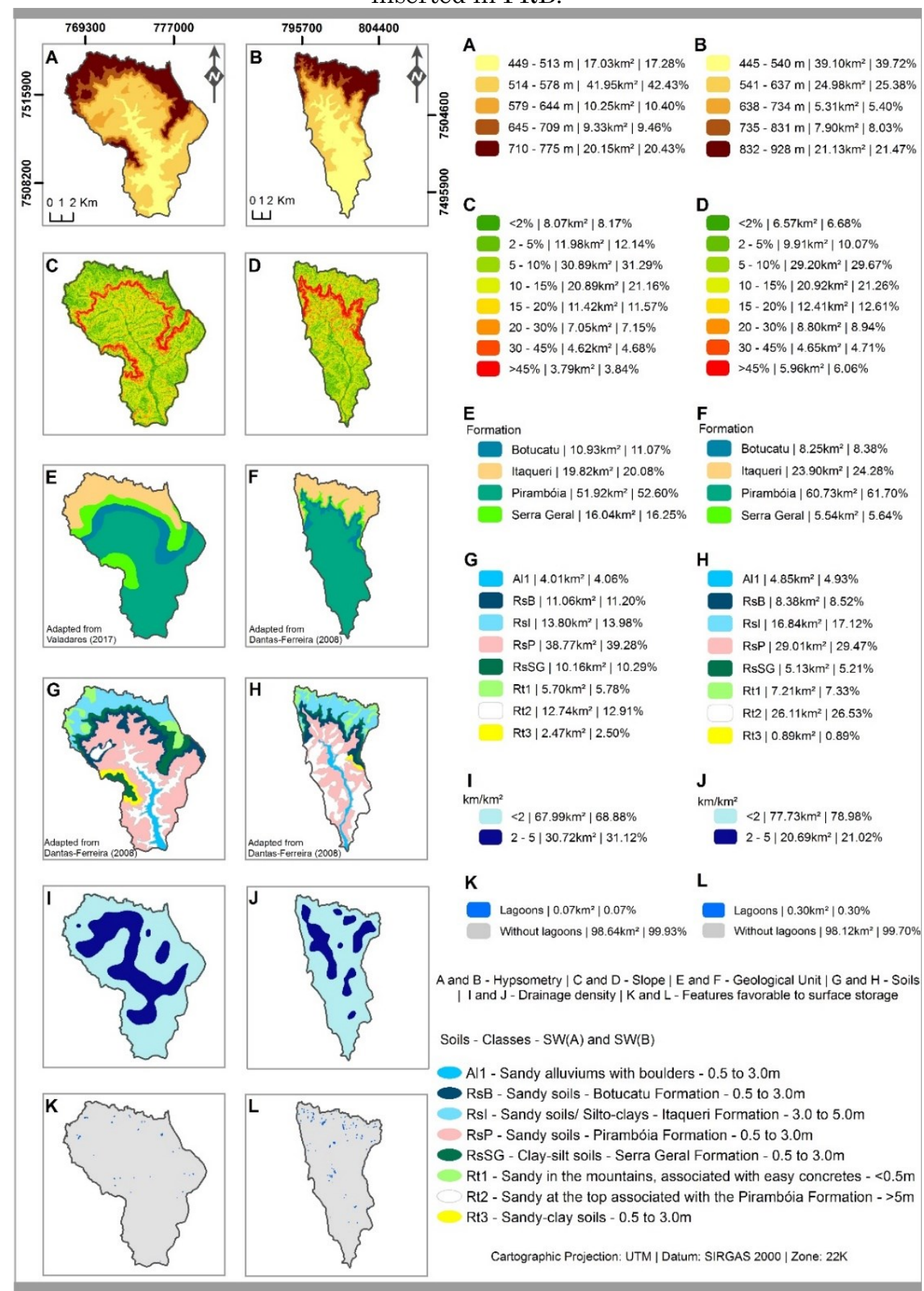

Source: The authors (2021). 
Figure 4 - Environmental attributes and their respective quantifications of sub-watersheds C and D inserted in PRB.

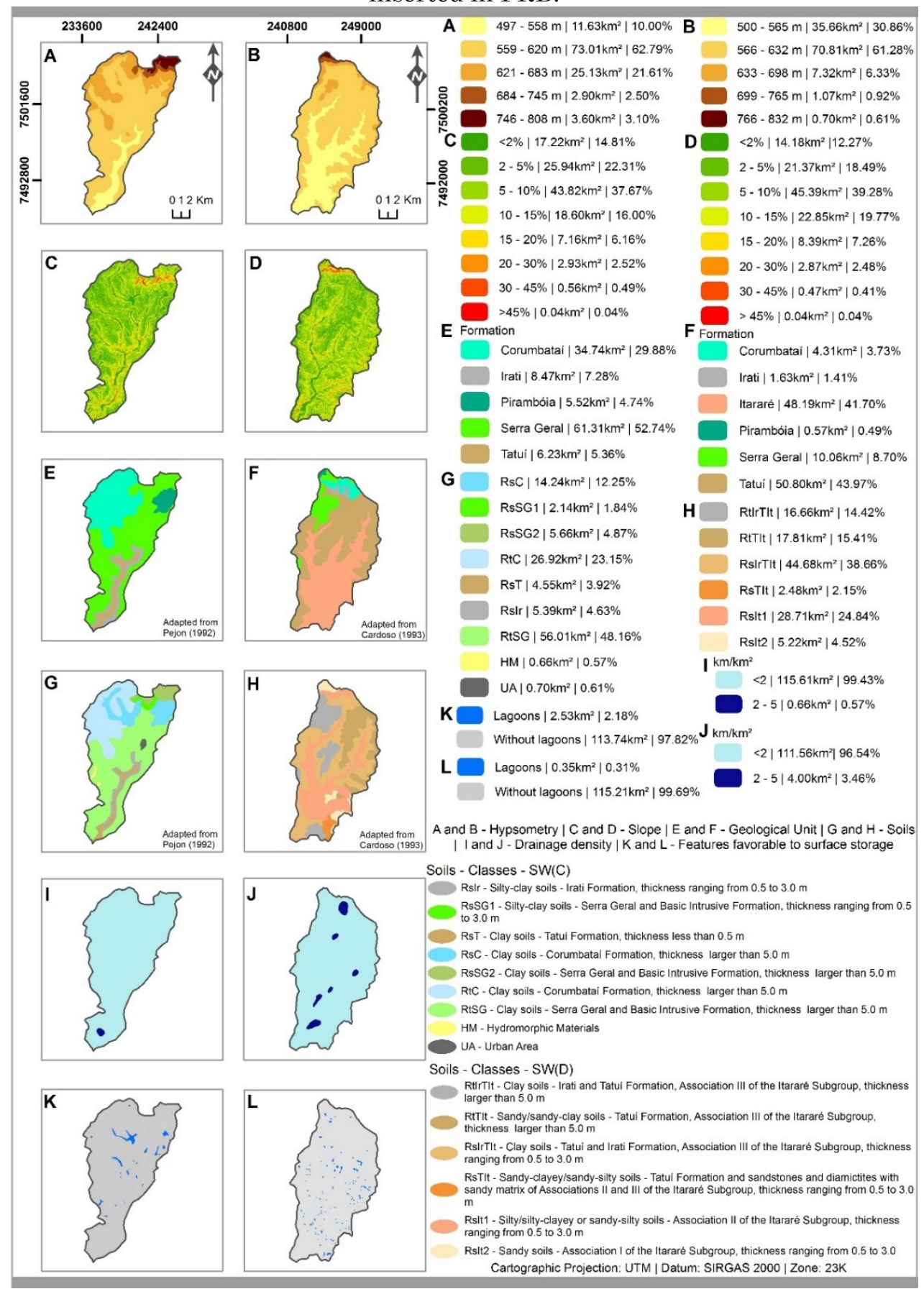

Source: The authors (2021).

The geological units of the two pairs of subbasins were obtained from bibliographic sources from previous works, as well as the soil maps.

Hypsometry was obtained based on AlosPalsar images with a spatial resolution of 12.5 by 12.5 meters, available free of charge through the ASF Data SearchVertex ${ }^{\circledR}$ platform. The images of the studied area were inserted in the ArcGIS10.5 ${ }^{\circledR}$ software, redesigned for the SIRGAS2000 datum, later classified into altitude ranges. These same images determined the slope, using the Slope command from
ArcGIS10.5 ${ }^{\circledR}$. Image processing allowed the generation of the Declivity classes were generated via image processing, in \%, and later reclassified, with the identification of 8 classes, where the lowest values $(<2 \%)$ received the lowest weight associated with the influence of flow, and the highest values (close to 45\%) obtained the highest score, as they would have a greater impact on its intensity.

Land use and land cover maps were prepared using the ArcGIS10.5 ${ }^{\circledR}$ software, based on RapidEye images, with a spatial resolution of 5 
meters, dated in June 2019, obtained free of charge in the Planet ${ }^{\circledR}$ Platform. The procedure of obtaining the maps involved reprojecting images using the software, changing the datum WGS84 to SIRGAS2000. Subsequently, a shapefile in the form of a polygon was created and then, using the Editor tool, polygons representing the classes of land usage that occupy the studied areas were made. The mapped classes were validated in the field (LORANDI et al., 2019).

The Google Earth Pro $^{\circledR}$ platform was used to obtain the water storage features, which allowed the delimitation of lagoons and dams in the study areas. This result, in . $\mathrm{kml}$ format, was inserted in the ArcGIS10.5 ${ }^{\circledR}$ software and transformed into shapefile formats and finally, the water storage features of land use and land cover maps were coupled.

\section{Surface Runoff Potential Chart}

Surface runoff is the process in which precipitated water flows through a channel in the catchment area after the surface and underground losses (CALETKA et al., 2020). The surface runoff potential charts were developed according to Pejon's proposal (1992), using the attributes: slope, lithology, soil texture/origin and thickness, drainage density, and features favorable to surface storage. The process of preparing the charts was performed in the Geographic Information System (GIS) (ArcGIS10.5 ${ }^{\circledR}$ software) using the Raster Calculator tool.

The drainage density was prepared using the ArcGIS10.5 ${ }^{\circledR}$ Kernel Density tool. The drainage network in the shapefile format was used as input data for processing. The Kernel radius value adopted was at 1128, representing approximately $4 \mathrm{~km}^{2}$, compatible with the drainage network scale (DIAS, 2013).

Figure 2 shows the weights assigned to each class of environmental attributes considering their surface runoff potential. Further, surface runoff potential charts were classified according to the values adopted in the Pejon methodology (1992), varying in 8 levels, which were considered 1-2 very low, 3-4 low, 5-6 medium, and 7-8 high surface runoff potential.

\section{RESULTS AND DISCUSSIONS}

\section{Analysis of the in situ measured flow and rainfall, associated with natural and anthropic environmental factors}

Several studies around the world are being carried out relating rain-flow to runoff aiming towards sustainable water management (JIAN; RYU; WANG, 2021; MAO et al., 2021; OKKAN et al., 2021; SHYAM et al., 2021; YIN et al., 2021).

Particularly in this work, flow and rainfall were measured in the field and analysed in the two pairs of sub-watersheds, in order to understand how these variables behave in morphometrically defined regions. Hydrologically resembling regions are linked to the basin's rainfall behaviour, which in turn relates to various conditions of these hydrographic regions. Therefore, knowing the characteristics of these areas is essential to understanding hydrology (CHOUBIN et al., 2019).

In the studied areas, there were months when flow and rainfall have not followed the same behaviour, especially regarding the directly proportional relationship between rainfall and flow, or the opposite. It is important to highlight that the precipitation-flow behaviour follows the characteristics of the watershed as well as the precipitation regime (KUMAR et al., 2021).

In order to comprehend this dynamic, attributes of the natural environment and land use and cover were integrated into the analysis, which when combined helped determine the surface runoff potential in the areas. Because the flow of rivers is directly influenced by climatic variation as well as anthropic activities, it is thus essential to distinguish the interventions of these two factors in a way that effective decisions for water resources management can be made (PIRNIA et al., 2019). Besides that, characteristics of the river basin should be taken into account, such as length, width, territorial extent, shape, soil type, as well as hydrological conditions that directly influence the rainfall-runoff relationship (CALETKA et al., 2020).

Climate change as well as land use and land cover act significantly in hydrological processes (RAHMAN et al., 2015). Malekian et al. (2019) states that it is necessary to homogenise data on human activities and historical data for water balance modelling, based on its study of a structure to improve the performance of flow modelling and water balance for the Delichay Basin, located in Iran.

\section{Pair 1 - SW(A) and $S W(B)$}

In the months of May to August, there was a dry period with monthly accumulated rainfall for SW(A) that did not exceed $30 \mathrm{~mm}$, while SW(B) in May and July 2019 exceeded just over 50mm, 
however comparing the two sub-water basins in the months (May, June and July 2019), the occurrence of rains was different, a fact that may be associated with the higher altimetry in SW(B) (Figure 5). It is commonly understood that altitude plays a major role in the spatial distribution of rainfall in mountainous regions.
The orographic barrier allows the air mass to expand and cool adiabatically, providing an increase in relative humidity, generating clouds and rain, which is the main reason for increasing accumulated precipitation related to altitude (SOKOL; BLIŽŇ́́K, 2009).

Figure 5 - Comparison between precipitation $(\mathrm{mm})$ and flow $\left(\mathrm{m}^{3} / \mathrm{s}\right)$ measured in situ in the period of twelve months for pair 1.

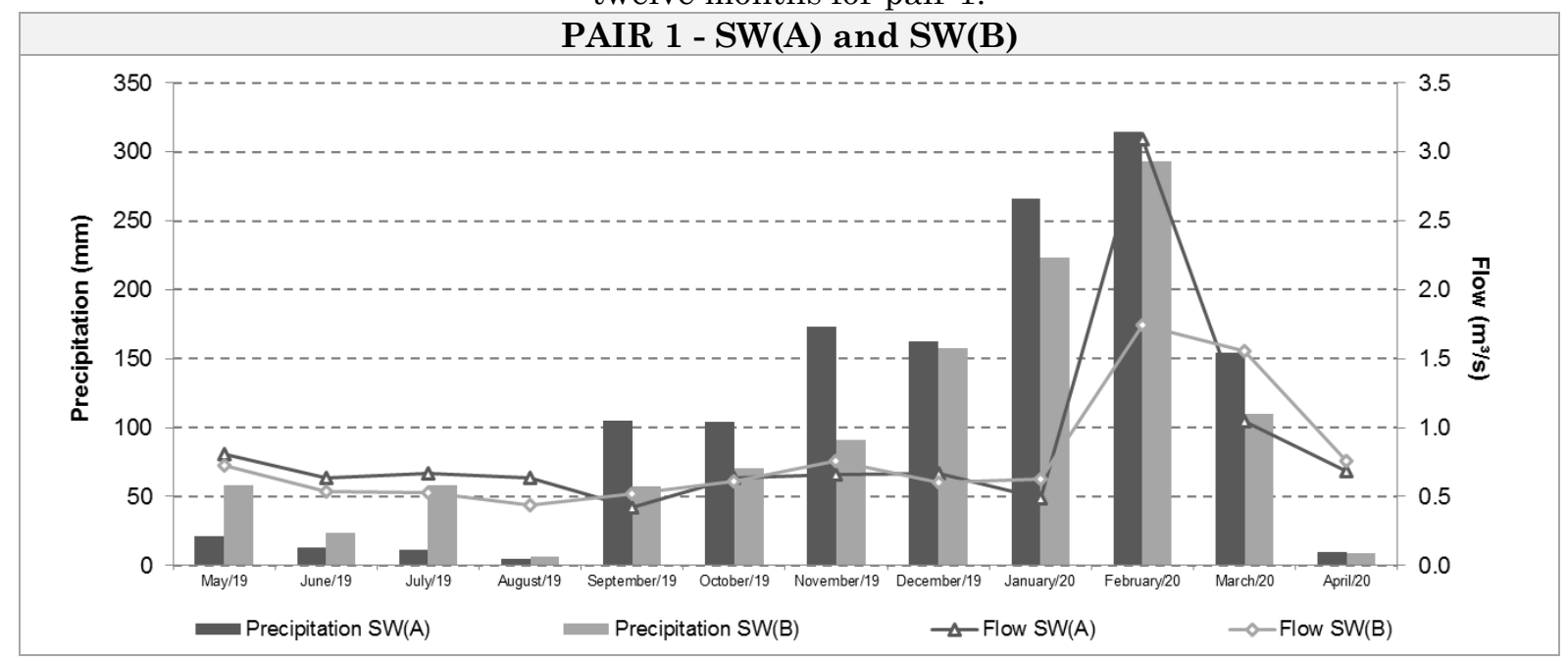

Source: The authors (2021).

In this period (May to August 2019), the flow in both sub-watersheds showed a level of constancy, but was slightly higher in SW(A) when compared to SW(B). Flows tend to vary less in the dry season, even with isolated rain events, as in the month of August. However, for SW(A) and SW(B), there was monthly accumulated precipitation in the order of $4.5 \mathrm{~mm}$ and $6.3 \mathrm{~mm}$, respectively, even in spite the fact that the flows did not decrease, which remained constant in previous months.

Monthly rainfall considering the months of September to November 2019 was different between the sub-basins. It is observed that in September and November, SW(A) had a lower flow compared to the flow measured in SW(B), even with the occurrence of a higher precipitation volume.

The fact that the occurrence of monthly accumulated precipitation was different and did not significantly affect the flow change from one sub-basin to another, may be related to the nature of the precipitation (BELL et al., 2012). Although in SW(A) there was a greater precipitated volume, this was not enough to contribute to flow increase, since both areas have sandy soils, which provide aquifer recharge, that is, they are characterized with greater infiltration capacity and consequently low surface runoff potential. Because of that, soil characteristics influence the flow velocity that acts by modifying soil infiltration capacity, soil shear strength and detachment rates (LIU et al., 2015; SUN; ZHOU; CAI, 2020).

When comparing flow and rainfall, it was observed that December was the period with the smallest difference between SW(A) and SW(B), considering the analyzed period of 12 months. As of November 2019, there was an increase in rainfall and it was observed that flows remained at a constant level until January 2020. In January and February 2020, the accumulated monthly rainfall exceeded $200 \mathrm{~mm}$, however in February, the flow rates increased markedly, in $\mathrm{SW}(\mathrm{A})$ it exceeded $3.0 \mathrm{~m}^{3} / \mathrm{s}$, and in $\mathrm{SW}(\mathrm{B})$ it was above $1.5 \mathrm{~m}^{3} / \mathrm{s}$.

This abrupt flow increase in February 2020 in pair 1 can be evidenced by the influence of the measurement date, since there were 24 hours of rain before the measurement, comprising a precipitated volume of $25.6 \mathrm{~mm}$ in $\mathrm{SW}(\mathrm{A})$ and $28.8 \mathrm{~mm}$ in $\mathrm{SW}(\mathrm{B})$, significantly increasing the flow.

Between the months of March and April 2020 , there was a clear decrease in rainfall and in situ measured flow, referring to the beginning of the dry period. In March, there was greater precipitation in SW(A) comprising $153.1 \mathrm{~mm}$, while in SW(B) the rainfall volume was $110.2 \mathrm{~mm}$; this variation was in the order of 42.9mm. Although SW(B) accumulated precipitation was smaller this month, the flow 
was greater when related to that of SW(A) and this situation can be explained by the distribution of high-intensity rains near the measurement period. In April, monthly rainfall was very close, including flows from the two subwatersheds.

Considering the analysed period, it appears that during the year, the two sub-watersheds generally showed water flow that did not exceed $1.0 \mathrm{~m}^{3} / \mathrm{s}$. There were only extrapolations in February and March 2020 with the occurrence of high-intensity rains close to the measurement period in the sub-watersheds, leading flow to increase considerably, in a phenomenon known as peak or flood flow.

The areas are located on sedimentary terrains, mostly composed of sandy soils from the Botucatu and Pirambóia formations, with thickness ranging from 0.5 to $3.0 \mathrm{~m}$, and their physical properties contribute to the infiltration process for aquifer recharge (ARANTES et al., 2021). These areas also include reworked soils located in the Serra de Torrinha, also with a sandy texture and thickness over $5.0 \mathrm{~m}$.

Regarding relief, the areas show a steep slope $(>45 \%)$ in the extreme north, more specifically in the Serra de Torrinha (located in SW(A)) and in the São Pedro mountain range (in SW(B)), in the rest the slopes are low to median. Further, the altimetric amplitude is $326 \mathrm{~m}$ and $483 \mathrm{~m}$, respectively, for SW(A) and SW(B). According to the area's morphometry, the drainage density is characterized as being sparse, because for over $60 \%$ of the total area of the sub-watersheds, the drainage density is less than $2 \mathrm{~km} / \mathrm{km}^{2}$.

Based on the mapping of existing lagoons and dams in the sub-watersheds, it can be stated that they do not significantly interfere with surface runoff, since they are well distributed and occupy small land areas, however, they favour evaporation and infiltration processes, tending to decrease surface runoff (PEJON, 1992).

Through surface runoff potential charts, the evaluation of the physical characteristics of the sub-basins showed that these areas have very low to low potential, indicating greater infiltration capacity, emphasizing that the process of water infiltration in the soil establishes the quantity of the rainfall-runoff behaviour (KUMAR et al., 2021). The factor that contributes to a higher surface runoff speed is the presence of the sloping region near its headwaters, directing the flow of precipitated water to flat areas, concentrated mainly in the central portion of these sub-watersheds (Figure $6)$.

Figure 6 - Surface Runoff Potential Chart. A: SW(A) from Rio da Prata and B: SW(B) from Ribeirão das Tabaranas.

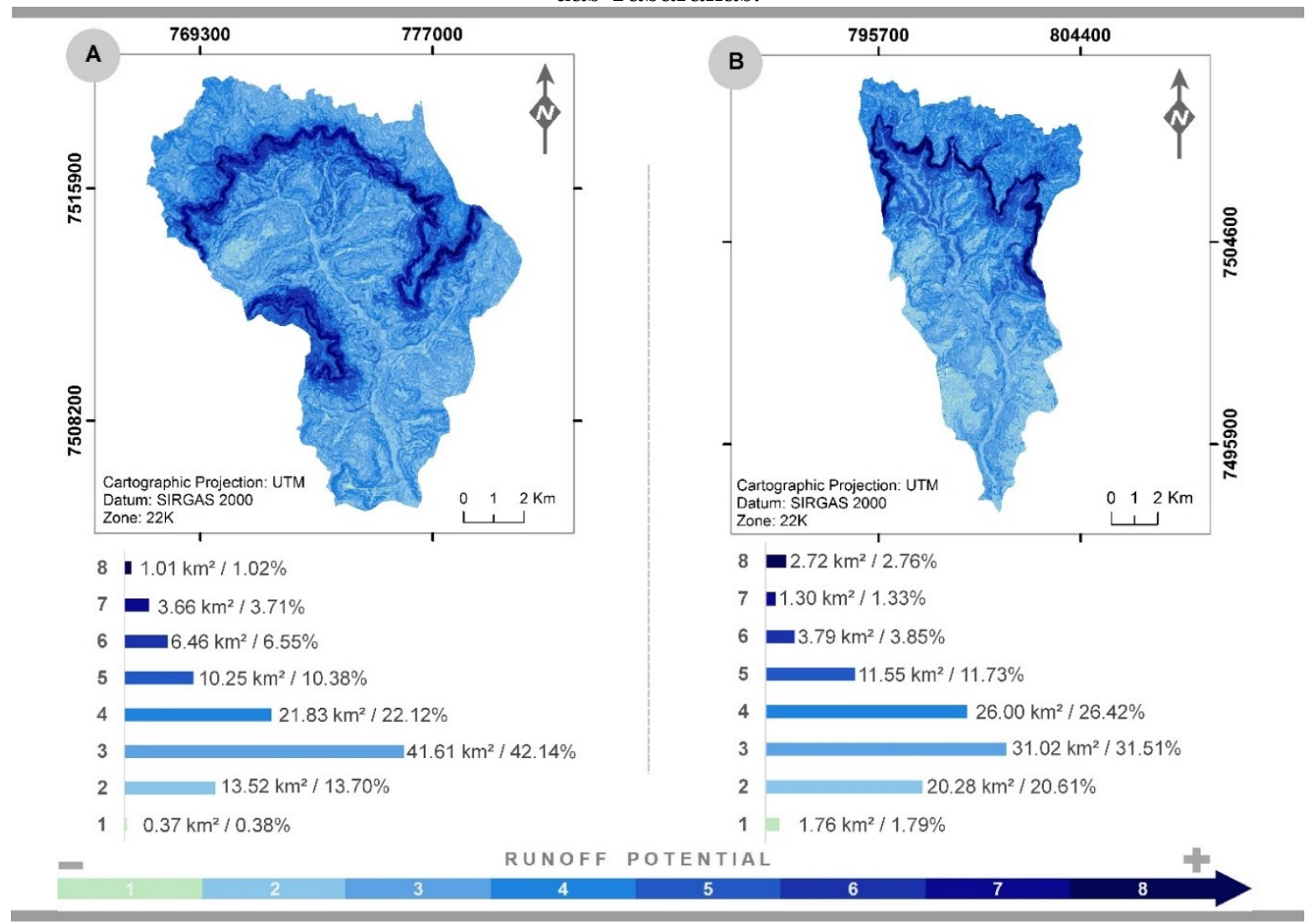

Source: The authors (2021). 
The anthropic attribute, land use and cover, partially justifies flow changes in this pair, as the SW(A) has larger agricultural areas that use irrigation systems. SW(B), even with greater crop diversity, has a smaller cultivated area that tends to require less water. Also, pair 1 does not have urbanized and industrial regions that make use of water resources. Regarding natural vegetation areas, $\mathrm{SW}(\mathrm{A})$ and $\mathrm{SW}(\mathrm{B})$ comprise $32.05 \mathrm{~km}^{2}$ and $37.09 \mathrm{~km}^{2}$ respectively. SW(A) basically stands out for having agricultural activities with the production of sugarcane $\left(28.66 \mathrm{~km}^{2}\right)$, citrus (orange, tangerine, lemon) $\left(7.26 \mathrm{~km}^{2}\right)$ and coffee $\left(0.04 \mathrm{~km}^{2}\right)$, while SW(B), in addition to presenting these crops, integrates permanent avocado crops $\left(0.03 \mathrm{~km}^{2}\right)$, as well as temporary cassava crops $\left(7.05 \mathrm{~km}^{2}\right)$.

It is noteworthy that any changes in land use and land cover intervene in surface flow, in the recharge of aquifers, in the process of infiltration, interception and evaporation of water, which directly affects the availability of water (SAJIKUMAR; REMYA, 2015; YAŞAR KORKANÇ, 2018). In fact, the southeastern portion of Brazil has shown, in recent decades, significant changes in land use and coverage, which corroborated with the decrease in precipitation since 2012 , directly influencing the availability of water for millions of people living in urban and rural areas (SORIANO et al., 2016).

\section{Pair 2 - SW(C) and $S W(D)$}

In pair 2, between May and October, there was a sharp decrease in the flow level in the subwatersheds (Figure 7). Even with a higher precipitated volume (May, July, August and September), a lower flow rate was observed in $\mathrm{SW}(\mathrm{D})$, when compared to $\mathrm{SW}(\mathrm{C})$. The flow rates in SW(D) are lower due to anthropogenic activities carried out in the area (CARVALHO et al., 2021).

Figure 7 - Comparison between precipitation $(\mathrm{mm})$ and flow $\left(\mathrm{m}^{3} / \mathrm{s}\right)$ measured in situ over a period of twelve months for pair 2 .

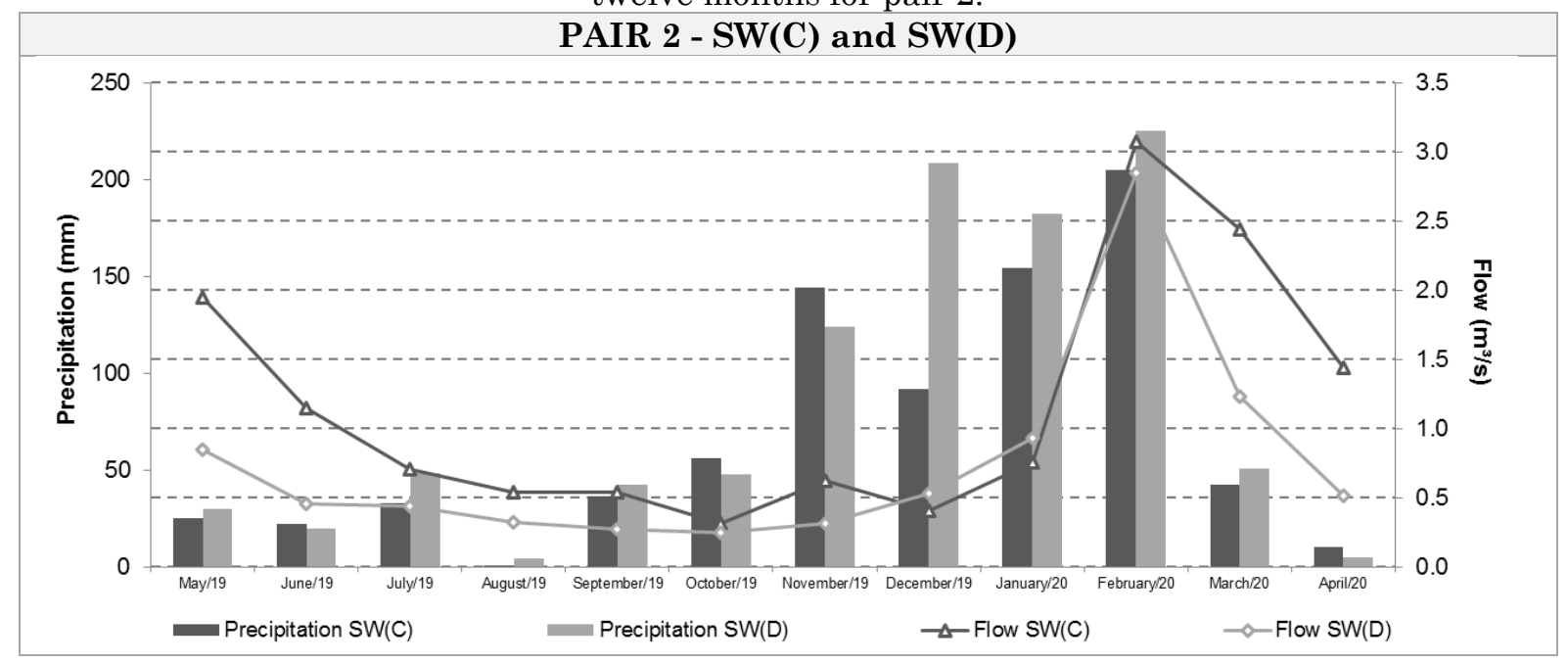

Source: The authors (2021).

This flow divergence in the sub-watersheds is observed in most of the months analysed and this situation is directly related to the use of water for irrigation and/or spraying and in citrus processing (orange, tangerine, lemon) in SW(D). In addition, there was the cultivation of sugarcane as raw material for the production of sugar and ethanol, where there is also a water demand for fertigation of the crop. Further, nurseries represent a consolidated economic activity in this sub-watershed that uses water to irrigate native, exotic, fruit and ornamental seedlings.

SW(D) presents a potential demand for water in agriculture considering temporary crops such as sugarcane, cassava, corn, soybeans, which demand, respectively, $39.389 .8 \mathrm{~m}^{3} /$ day, 99.9 $\mathrm{m}^{3} /$ day, $170.9 \mathrm{~m}^{3} /$ day, $50.4 \mathrm{~m}^{3} /$ day. Regarding permanent crops, banana plantation areas have a potential demand of $176.8 \mathrm{~m}^{3} /$ day, citrus crops $4266.7 \mathrm{~m}^{3} /$ day, $126.1 \mathrm{~m}^{3} /$ day for coffee plantations, $22.0 \mathrm{~m}^{3} /$ day for mango crops. In addition, the nurseries demand $30,296.7 \mathrm{~m}^{3} /$ day (CARVALHO et al., 2021).

From November 2019 to February 2020, there were noticeable increases in precipitated volumes resulting from the rainy season. In December 2019, precipitation varied considerably in the sub-watersheds and was in the order of importance of $126.9 \%$, comprising a higher precipitated volume of $116.5 \mathrm{~mm}$ in $\mathrm{SW}(\mathrm{D})$, however, even in this condition its flow 
remained very close in relation to $\mathrm{SW}(\mathrm{C})$. This fact is associated with rain distribution throughout the month in SW(D), not directly interfering in surface flow.

In pair 2, in these twelve months of analysis, the peak considering greater flows and precipitated monthly volumes, occurred precisely in February 2020, with flows and precipitations that showed great similarity when compared. The flow increase in February 2020 , as in pair 1 , is a reflection of the measurement date, since the incidence of precipitation occurred in previous hours.

The decrease in precipitation in the months of March and April 2020 marked the beginning of the dry period, which clearly showed the gradual flow decrease in both sub-watersheds. However, the flow level was quite different from one to the other, observed in March 2020, when the flow in $\mathrm{SW}(\mathrm{C})$ was close to $2.5 \mathrm{~m}^{3} / \mathrm{s}$, and in
$\mathrm{SW}(\mathrm{D})$ the measured flow was $1.23 \mathrm{~m}^{3} / \mathrm{s}$. This was repeated in April, as in SW(C) the flow was three times the value found in SW(D). As a result of the dry period, SW(D) had a higher water requirement for developing its agricultural activities.

Thus, when considering the analysed period, it is observed that SW(D) had the most intense use of water resources when compared to $\mathrm{SW}(\mathrm{C})$, even though it presented a predominance of sugarcane cultivation, and the existence of two dams that supply the urban area of the municipality of Iracemápolis.

Based on the characteristics of the natural environment, it appears that surface runoff has great potential to be very low to low in both subbasins, for $\mathrm{SW}(\mathrm{C})$ and $\mathrm{SW}(\mathrm{D})$ it presents a percentage of the total area above $60 \%$ (Figure 8).

Figure 8 - Surface Runoff Potential Chart. A: SW(C) from Ribeirão da Cachoeira, B: SW(D) from Córrego dos Coqueiros.

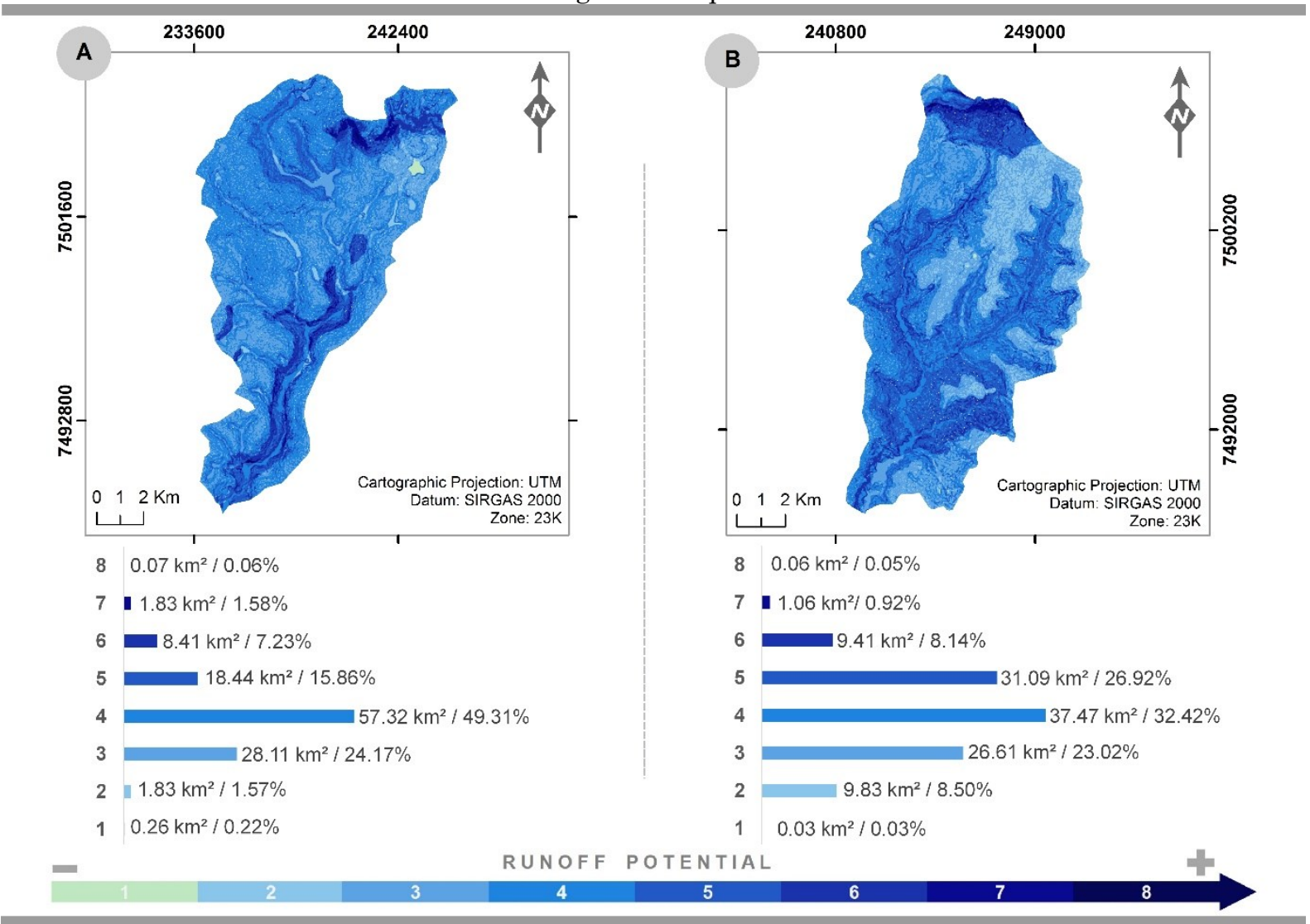

Source: The authors (2021).

The classes of low surface runoff potential in these areas are mainly due to the predominance of flat relief in the sub-watersheds. Their soils present a higher fraction of silt and clay, with thicknesses $>5 \mathrm{~m}$ in $\mathrm{SW}(\mathrm{C})$ and varying from $0.5 \mathrm{~m}$, reaching depths above $5 \mathrm{~m}$ in $\mathrm{SW}(\mathrm{D})$. Despite the fact that the physical properties of these soils do not provide a low flow, when associated with low land slope, geological characteristics and low drainage density are configured in regions where the flow flows more slowly, contributing to the evaporation process and more discreetly with infiltration. The higher runoff potential is concentrated in the northern 
region of both areas, as it presents a steep slope $(>30 \%)$, contributing to a higher flow speed.

\section{FINAL CONSIDERATIONS}

The selection of fourth-order sub-watersheds used in the study, with field collections related to natural and anthropic factors, allowed for a clear understanding of the water regime during the considered period.

The preparation of surface runoff potential charts based on the local conditions of the natural environment was fundamental to clarify the apparent discrepancies between rainfall and flow, showing the effectiveness of the method.

In pair 1 , the areas are predominantly composed of sandy soils, with thickness varying from $0.5 \mathrm{~m}$ to $3.0 \mathrm{~m}$, on terrain with a slope between $<2 \%$ to $10 \%$. While in pair $2, \mathrm{SW}(\mathrm{C})$ is composed mainly of silty-clayey to clayey soils from the Corumbataí, Irati, Tatuí and Serra Geral Formations. In SW(D) the soils have the same texture including porous clay reworked soil, these areas also show smooth slopes $(<2 \%$ to $10 \%$ ), highlighting the low surface runoff potential.

The analysis carried out in this study, considering small watersheds, allowed to obtain flow values that represent the hydrological reality of the areas, since their specificities were considered in detail.

During the analysed period, variations were observed in the flow rates of the pairs of subwatersheds. Land use and cover partially justify the flow changes in pair 1, as SW(A) has a greater extension of agricultural areas that can use irrigation. SW(B), even with a greater crop variety, presents a smaller cultivated area that tends to demand less water.

In pair 2, this attribute partially justifies too the flow fluctuations, due to the anthropic activities in SW(C) and SW(D), such as citrus crop irrigation and spraying, the sugarcane fertigation, the irrigation of seedling nurseries, representing activities that demand larger water volumes, directly interfering in the availability of surface water. Another factor that clarifies the lower flows in these sub-basins includes the association of fine texture soils with the class of higher runoff potential, reducing infiltration in the rainy period, which decreases base runoff in the dry period.

The adopted procedures can be applied in any hydrographic region that obtains the analysis data, since the results assist managers and planners in their decision making, which helps to establish guidelines that strive for the use and rational control of water courses.

\section{ACKNOWLEDGEMENTS}

The authors are grateful for the financial support of the Fundação de Amparo à Pesquisa do Estado de São Paulo (FAPESP), made available to Process No. 2018 / 14145-4, and claimed that "this work was carried out with the support of the Coordenação de Aperfeiçoamento de Pessoal de Nível Superior Pessoal - Brazil (CAPES)" - Financing Code 001.

\section{FUNDING SOURCE}

Fundação de Amparo à Pesquisa do Estado de São Paulo (FAPESP) - Process: n²018/14145-4

\section{REFERENCES}

AGÊNCIA DAS BACIAS PCJ. Relatório de situação dos recursos hídricos 2020 (ano base 2019). 2021. Available: https://agencia.baciaspcj.org.br/instrumentode-gesto/relatorios-de-situacoes/. Accessed in: 14 dez. 2021.

ANA - Agência Nacional de Águas e Saneamento Básico. Caderno de Capacitação em Recursos Hídricos - Outorga de Direito de Uso de Recursos Hídricos, 2011.

ANA - Agência Nacional de Águas e Saneamento Básico. Base Hidrográfica Ottocodificada das Bacias Hidrográficas do Piracicaba, Capivari e Jundiaí, 2013. Available: https://metadados.ana.gov.br/geonetwork/srv/ pt/main.home. Accessed in: 10 November 2019.

ARANTES, L. T. et al. Surface runoff associated with climate change and land use and land cover in southeast region of Brazil. Environmental Challenges, v. 3, n. February, p. 100054, 2021. https://doi.org/10.1016/j.envc.2021.100054.

ASF Data Search Vertex. Digital Elevation Model. 2021.2 Available: https://search.asf.alaska.edu/\#/. Accessed in: 20 August 2021.

BELL, V. A. et al. How might climate change affect river flows across the Thames Basin? An area-wide analysis using the UKCP09 Regional Climate Model ensemble. Journal of Hydrology, v. 442-443, p. 89-104, 2012. http://dx.doi.org/10.1016/j.jhydrol.2012.04.001 
BESKOW, S. et al. Potential of the LASH model for water resources management in datascarce basins: a case study of the Fragata River basin, southern Brazil. Hydrological Sciences Journal, v. 61, n. 14, p. 2567-2578, 2016.

https://doi: 10.1080/02626667.2015.1133912.

CALETKA, M. et al. Improvement of SCS-CN initial abstraction coefficient in the Czech Republic: A study of five catchments. Water (Switzerland), v. 12, n. 7, p. 1-28, 2020. https://doi.org/10.3390/w12071964.

CARDOSO, A. B. F. Mapeamento Geotécnico do município de Limeira - SP. Dissertation, University of São Paulo, 1993.

CARVALHO, A.C.P.; CARVALHO, A.P.P.; DI LOLLO, J.A.; COLLARES, E.G.; LORANDI, R., MOSCHINI, L.E. Proposta de método para a escolha de áreas de drenagem amostrais e suas relações com variáveis hidrológicas na região sudeste do Estado de São Paulo - Brasil. Revista de Gestão Água da América Latina, 17, $1-16$, 2020 . https://doi.org/10.21168/rega.v17e10.

CARVALHO, A. P. P. et al. Potential water demand from the agricultural sector in hydrographic sub-basins in the southeast of the state of São Paulo-Brazil. Agriculture, Ecosystems and Environment, v. 319, n. January, 2021. https://doi.org/10.1016/j.agee.2021.107508.

CHOUBIN, B. et al. Streamflow regionalization using a similarity approach in ungauged basins: Application of the geo-environmental signatures in the Karkheh River Basin, Iran. Catena, v. 182, n. March, p. 104128, 2019. https://doi: 10.1016/j.catena.2019.104128.

COMITÊ DAS BACIAS PCJ. Relatório de Situação dos Recursos Hídricos Ano Base 2018. Piracicaba: Agências das Bacias PCJ, 2019. Available:

http://www.agencia.baciaspcj.org.br/novo/instr umentos-de-gestao/relatorios-de-situacoes.

Accessed in: 10 February 2020.

DANTAS-FERREIRA, M. Proposta de índice de processos erosivos acelerados a partir de levantamento e diagnóstico GeológicoGeotécnico de áreas degradadas. Thesis, University of São Paulo, 2008.

DENG, W. et al. Isolating of climate and land surface contribution to basin runoff variability: A case study from the Weihe River Basin, China. Ecological Engineering, v. 153, n. May, p. 105904, 2020. https://doi:10.1016/j.ecoleng.2020.105904.

DIAS, C. C. Avaliação geoambiental da região do Médio Rio Grande. 2013. Dissertação (Mestrado em Geotecnia) - Escola de Engenharia de São Carlos, University of São
Paulo, São Carlos, 2013. https://doi:10.11606/D.18.2013.tde-04082014102216.

FERREIRA, S. C. G.; DE LIMA, A. M. M.; CORREAA, J. A. M. Indicators of hydrological sustainability, governance and water resource regulation in the Moju river basin (PA) Eastern Amazonia. Journal of Environmental Management, v. 263, n. March, 2020. https://doi: 10.1016/j.jenvman.2020.110354.

GOOGLE EARTH PRO. Version 7.3. 2021. https://www.google.com.br/earth/download/ge p/agree.html.

JIAN, J.; RYU, D.; WANG, Q. J. A water-level based calibration of rainfall-runoff models constrained by regionalized discharge indices. Journal of Hydrology, p. 126937, 2021. https://doi.org/10.1016/ j.jhydrol.2021.126937.

KUMAR, A. et al. Surface runoff estimation of Sind river basin using integrated SCS-CN and GIS techniques. HydroResearch, v. 4, p. 6174 , 2021. https://doi.org/10.1016/j.hydres.2021.08.001.

LELIS, L. C. DA S. et al. Assessment of hydrological regionalization methodologies for the upper Jaguari River basin. Journal of South American Earth Sciences, v. 97, n. July 2019, $2020 . \quad$ https://doi: 10.1016/j.jsames.2019.102402.

LIU, D. et al. Rainfall intensity and slope gradient effects on sediment losses and splash from a saline-sodic soil under coastal reclamation. Catena, v. 128, p. 54-62, 2015. http://dx.doi.org/10.1016/j.catena.2015.01.022.

LOPES, T. R. et al. Hydrological modeling for the Piracicaba River basin to support water management and ecosystem services. Journal of South American Earth Sciences, v. 103, n. July, 2020. https://doi.org/10.1016/j.jsames.2020.102752.

LORANDI, R.; DI LOLLO, J.A.; MOSCHINI, L.E.; COLLARES, E.G.; CARVALHO, A.C.P.; CARVALHO, A.P.P. Análise espacial da disponibilidade hídrica nas Sub-bacias Hidrográficas do Rio Piracicaba (SP) para a proposição de instrumento de planejamento e gestão dos recursos hídricos. Relatório Parcial de Pesquisa. UFSCar/FAPESP - Processo: 2018/14145-4, 2019.

MALEKIAN, A. et al. Development of a New Integrated Framework for Improved RainfallRunoff Modeling under Climate Variability and Human Activities. Water Resources Management, v. 33, n. 7, p. 2501-2515, 2019. https://doi: 10.1007/s11269-019-02281-0.

MAO, G. et al. Comprehensive comparison of artificial neural networks and long short-term memory networks for rainfall-runoff 
simulation. Physics and Chemistry of the Earth, v. 123, p. 103026, 2021. https://doi.org/10.1016/j.pce.2021.103026.

MEHBOOB, M. S.; KIM, Y. Effect of climate and socioeconomic changes on future surface water availability from mountainous water sources in Pakistan's Upper Indus Basin. Science of the Total Environment, v. 769, p. 144820, 2021.https://doi.org/10.1016/j.scitotenv.2020.1 44820

MELATI, M. D.; MARCUZZO, F. F. N. Regressões simples e robusta na regionalização da vazão Q95 na Bacia Hidrográfica do Taquari-Antas Simple and robust regressions in flows regionalization of Q95 in Taquari-Antas river basin. Ciencia e Natura, v. $38, \quad$ p. $722-739,2016$. https://doi.org/10.5902/2179460X19800.

OKKAN, U. et al. Embedding machine learning techniques into a conceptual model to improve monthly runoff simulation: A nested hybrid rainfall-runoff modeling. Journal of Hydrology, v. 598, n. May, p. 126433, 2021. https://doi.org/10.1016/j.jhydrol.2021.126433.

PEJON, O. J. Mapeamento Geotécnico de Piracicaba. 1:100.000: Estudo de Aspectos Metodológicos de Caracterização e de Apresentação dos Atributos. Thesis, University of São Paulo, 1992.

PIRNIA, A. et al. Contribution of climatic variability and human activities to stream flow changes in the Haraz River basin, northern Iran. Journal of Hydro-Environment Research, v. 25, n. April, p. 12-24, 2019. https://doi: 10.1016/j.jher.2019.05.001.

PLANET. Imagens RapidEye 2019. https://www.planet.com/. Accessed in: 10 November 2019.

RAHMAN, K. et al. An independent and combined effect analysis of land use and climate change in the upper Rhone River watershed, Switzerland. Applied Geography， v. 63， p. 264-272, 2015. https://doi: 10.1016/j.apgeog.2015.06.021.

RAO, A. R.; SRINIVAS, V. V. Regionalization of watersheds by fuzzy cluster analysis. Journal of Hydrology, v. 318, n. 1-4, p. 57-79, 2006. https://doi: 10.1016/j.jhydrol.2005.06.004.

SAJIKUMAR, N.; REMYA, R. S. Impact of land cover and land use change on runoff characteristics. Journal of Environmental Management, v. 161, p. 460-468, 2015. http://dx.doi.org/10.1016/j.jenvman.2014.12.04 1.

SANTOS, I.; FILL, H.D.; SUGAI, M.R.V.B.; BUBA, H.; KISHI, R.T.; MARONE, E.; LAUTERT, L.F. Hidrometria aplicada. Instituto de Tecnologia para o Desenvolvimento, LACTEC, Curitiba, 2001.
SHYAM, G. M. et al. Sustainable water management using rainfall-runoff modeling: A geospatial approach. Groundwater for Sustainable Development, v. 15, n. August, p. 100676, 2021. https://doi.org/10.1016/j.gsd.2021.100676.

SOKOL, Z.; BLIŽŇÁK, V. Areal distribution and precipitation-altitude relationship of heavy short-term precipitation in the Czech Republic in the warm part of the year. Atmospheric Research, v. 94, n. 4, p. 652-662, 2009. https://doi.10.1016/j.atmosres.2009.03.001.

SORIANO, É. et al. Water crisis in São Paulo evaluated under the disaster's point of view. Ambient. $\quad$ Soc., 19, p. 21-42, 2016. https://doi.org/10.1590/1809-

4422 asoc150120r1v1912016.

SSRH - Secretaria de Saneamento e Recursos Hídricos. Situação dos recursos hídricos no estado de São Paulo 2016. 2018. Available: http://www.sigrh.sp.gov.br/relatoriosituacaodo srecursoshidricos. Accessed in: 18 August 2020.

STRAHLER, A. N. Quantitative analysis of watershed geomorphology. New Halen: Trans Am Geophys Union 38:913-920, 1957. https://doi.org/10.1029/TR038i006p00913.

SUMAN, M.; MAITY, R. Hybrid Wavelet-ARX approach for modeling association between rainfall and meteorological forcings at river basin scale. Journal of Hydrology, v. 577, n. July, p. 123918, 2019. https://doi: 10.1016/j.jhydrol.2019.123918.

SUN, L.; ZHOU, J. L.; CAI, Q. Impacts of soil properties on flow velocity under rainfall events: Evidence from soils across the Loess Plateau. Catena, v. 194, n. May, p. 104704, 2020.

https://doi.org/10.1016/j.catena.2020.104704.

TIKHAMARINE, Y. et al. Rainfall-runoff modelling using improved machine learning methods: Harris hawks optimizer vs. particle swarm optimization. Journal of Hydrology, v. 589, n. June, p. 125133, 2020. https://doi: 10.1016/j.jhydrol.2020.125133.

TUNDISI, J.G.; TUNDISI, T. M. As múltiplas dimensões da crise hídrica. 2015. Rev USP 21. https://doi.org/10.11606/issn.23169036.v0i106p21-30.

VALADARES, A. P. Mapeamento pedológico digital por mineração de dados: bases de treinamento para o nível de reconhecimento. Dissertation, Agronomic Institute of Campinas, 2017.

XAVIER, A. L. dos S. A contribuição dos Comitês de Bacia Estadual e Federal à gestão das bacias hidrográficas dos rios Piracicaba, Capivari e Jundiai, em São Paulo: ações mais relavantes, perspectivas e desafios (1993- 
2006). 2006. Dissertação (Mestrado em Planejamento Urbano e Regional) - Faculdade de Arquitetura e Urbanismo, University of São Paulo, São Paulo, 2007. https://doi:10.11606/D.16.2007.tde-19092007123444.

WADA, Y.; BIERKENS, M. F. P. Sustainability of global water use: Past reconstruction and future projections. Environmental Research Letters, v. 9, n. 10, 2014. https://doi.org/10.1088/17489326/9/10/104003.

WANG, H.; CHEN, L.; YU, X. Distinguishing human and climate influences on streamflow changes in Luan River basin in China. Catena, v. 136, p. 182-188, 2016. https://doi.org/10.1016/j.catena.2015.02.013.

YAŞAR KORKANÇ, S. Effects of the land use/cover on the surface runoff and soil loss in the Niğde-Akkaya Dam Watershed, Turkey. Catena, v. 163, n. August 2017, p. 233-243, 2018.

https://doi.org/10.1016/j.catena.2017.12.023.

YIN, H. et al. Rainfall-runoff modeling using LSTM-based multi-state-vector sequence-tosequence model. Journal of Hydrology, v. 598, n. October 2020, p. 126378, 2021. https://doi.org/10.1016/j.jhydrol.2021.126378.
YU, Z. et al. Preface: Hydrological processes and water security in a changing world. Proceedings of the International Association of Hydrological Sciences, v. $383, \quad$ n. $4, \quad$ p. $3-4, \quad 2020$. https://doi.org/10.5194/piahs-383-3-2020.

\section{AUTHORS' CONTRIBUTION}

Ana Claudia Pereira Carvalho performed the fluviometric and pluviometric monitoring in the field, applied the methods, as well as elaborated the results and wrote the paper. Reinaldo Lorandi validated the data and information, analyzed the results and contributed to the writing of the paper. José Augusto Di Lollo validated the data and information, analyzed the results and contributed to the writing of the paper. Eduardo Goulart Collares validated the data and information, analyzed the results and contributed to the writing of the paper. Luiz Eduardo Moschini validated the data and information, analyzed the results and contributed to the writing of the paper. 